\title{
Bakteri resisten merkuri pada feses pasien tumpatan amalgam di Poli Gigi Puskesmas Bahu Manado
}

\author{
Geby V. Wardalina \\ Kandidat Skripsi Fakultas Kedokteran Universitas Sam Ratulangi Manado \\ Email: gabyvelanda@yahoo.com
}

\begin{abstract}
Amalgam is an ingredient for filling the affected tooth caries. It is a special mixture of metals containing mercury. Mercury is a natural heavy metal that has bad impact on human health. Mercury in amalgam can be released into the oral cavity and absorbed via the digestive tract, and then excreted via urine and feces. This study aimed to obtain the bacteria which were resistant to mercury in feces. This was a descriptive explorative study. Samples were taken from the stool of three patients with amalgam fillings at Dental Clinic Primary Health Center Bahu. The three patients had used amalgam fillings at least 5 years. Samples were tested morphologically, physiologically, and biochemically at the Laboratory of Biotechnology, University of Sam Ratulangi Manado. The results showed that there were 2 genus of mercury-resistant bacteria at mercury concentration of $40 \mathrm{ppm}$, namely Bacillus sp and Escherichia coli.
\end{abstract}

Keywords: Amalgam, bacteria, feces, mercury

\begin{abstract}
Abstrak: Amalgam merupakan bahan untuk merestorasi gigi yang terkena karies. Amalagam adalah jenis logam campur khusus yang mengandung merkuri. Merkuri merupakan logam berat alamiah yang bisa berdampak buruk bagi kesehatan manusia. Merkuri pada amalgam bisa terlepas ke kavum oris, diabsorpsi ke dalam saluran pencernaan, lalu diekskresikan melalui urine dan feses. Penelitian ini bertujuan untuk mengetahui bakteri yang resisten terhadap merkuri dalam feses pada pasien dengan tumpatan amalgam. Jenis penelitian ini ialah deskriptif eksploratif. Sampel feses diambil dari 3 pasien dengan tumpatan amalgam di Poli Gigi Puskesmas Bahu yang telah menggunakan tumpatan amalgam minimal 5 tahun kemudian diuji secara morfologik, fisiologik, dan biokimia di Laboratorium Bioteknologi FMIPA Universitas Sam Ratulangi Manado. Hasil penelitian mendapatkan 2 genus bakteri resisten merkuri yang bertahan sampai konsentrasi merkuri 40 ppm, yaitu Bacillus sp dan E. Coli
\end{abstract}

Kata kunci: amalgam, bakteri, feses, merkuri

Amalgam adalah campuran dari paduan logam (aloi) dan air raksa (Hg). Amalgam merupakan bahan untuk merestorasi gigi yang terkena karies. Bahan tersebut masih banyak digunakan oleh dokter gigi dengan pertim-bangan bahwa bahan tersebut mudah dimanipulasi, harga relatif murah, dan cukup kuat menahan daya kunyah. Combe melaporkan mengenai pelepasan Hg dari restorasi amalgam yang ada dalam mulut namun tidak sampai mengalami keracunan karena kadar Hg tersebut kecil. ${ }^{1}$
Triturasi amalgam dapat dilakukan dengan cara manual dan masinal. Cara manual dilakukan dengan menggunakan alu dan mortal. ${ }^{1}$ Homogenitas amalgam tergantung dari tekanan yang terjadi antara alu dan lumpang. Tekanan yang berbedabeda dari operator menyebabkan kekuatan amalgam yang berbeda homogenitasnya sehingga hasilnya kurang baik. Lain halnya dengan cara masinal yang tekanannya selalu sama sehingga menghasilkan amalgam yang homogen. ${ }^{2}$ 
Menurut Marek pelepasan Hg dari dental amalgam dapat terjadi sejak dilakukan kondensasi amalgam di dalam mulut dan terus berlangsung selama amalgam berada di dalam mulut. Hg yang larut di dalam saliva dapat masuk ke dalam tubuh manusia melalui pencernaan, pernafasan dan diabsorbsi melalui mukosa mulut. $^{3} \quad \mathrm{Hg}$ dapat diabsorbsi melalui jaringan paru-paru dan pencernaan kemudian masuk ke dalam aliran darah. Di dalam tubuh, $\mathrm{Hg}$ terikat dengan protein yang mempunyai gugus S-S yang berfungsi mentransfer logam berat ke hati dan ginjal. Pengeluaran $\mathrm{Hg}$ dari dalam tubuh dapat melalui kulit (keringat), ginjal (urin) dan saluran pencernaan (tinja). ${ }^{4}$

Diperkirakan terdapat 100 triliun selsel bakteri di dalam tubuh dan jumlah ini lebih banyak 10 kali lipat dari jumlah selsel manusia. Bakteri beredar di seluruh tubuh. Bakteri komensal dapat meningkatkan kesehatan atau sebaliknya jika mendapat masalah dari luar tubuh justru bakteri komensal akan hilang dan berubah menjadi patogen. ${ }^{4}$ Colibacteria relatif tidak berbahaya, terdapat dalam usus manusia dan hewan dalam jumlah besar. Bakteri ini berperan penting dalam pencernaan makanan. Colibacteria dalam feses (Enterobacteriaceae) ialah subkelompok colibacteria dan Escherichia coli (E. coli) merupakan salah satu spesies colibacterium yang sering ditemukan dalam feses. ${ }^{5}$

\section{METODE PENELITIAN}

Jenis penelitian ini ialah deskriptif eksploratif. Penelitian ini dilakukan sejak bulan Agustus 2012-Desember 2012 bertempat di Puskesmas Bahu dan Laboratorium Bioteknologi Fakultas MIPA Universitas Sam Ratulangi Manado. Populasi penelitian ialah bakteri pada feses pasien yang berkunjung di Poli Gigi Puskesmas Bahu Manado. Sampel penelitian diambil dari 3 koloni bakteri dari feses pasien di Poli Gigi yang menggunakan tumpatan amalgam minimal 5 tahun. Variabel penelitian ialah bakteri resisten merkuri.

Sampel feses sebanyak 0,5-1 ml dari pasien poli gigi dengan tumpatan amalgam diambil dengan bantuan disposable injection (tanpa jarum suntik). Sebanyak $1001 / 4 \mu \mathrm{L}$ larutan jernih sampel yang telah disuspensi dalam buffer salin diinokulasi pada media nutrient broth (yeast extract 2 $\mathrm{g} / \mathrm{L}$, bacto pepton $5 \mathrm{~g} / \mathrm{L}, \mathrm{NaCl} 5 \mathrm{~g} / \mathrm{L}$ ) dan diinkubasi pada temperatur $37^{0} \mathrm{C}$ selama 12-16 jam.

Sebanyak $100 \quad 1 / 4 \mu \mathrm{L}$ larutan jernih sampel yang telah disuspensi dalam buffer salin diinokulasi pada media nutrient broth (yeast extract $2 \mathrm{~g} / \mathrm{L}$, bacto pepton $5 \mathrm{~g} / \mathrm{L}$, $\mathrm{NaCl} 5 \mathrm{~g} / \mathrm{L})$ dan diinkubasi pada temperatur $37^{\circ} \mathrm{C}$ selama $12-16$ jam.

Identifikasi bakteri dilakukan dengan cara uji morfologi, fisiologi, dan biokimia. Uji morfologi dilakukan dengan perwarnaan Gram dan diperiksa di bawah mikroskop pada pembesaran 1000 kali. Hasil pengamatan dicatat kemudian difoto.

Uji fisiologi dilakukan dengan uji motility. Uji bersifat positif bila terlihat adanya pertumbuhan melebar dari bekas tusukan jarum ose.

Uji biokimia meliputi uji fermentasi karbohidrat. Reaksi positif ditunjukan dengan perubahan warna pada media menjadi warna lembayung (violet), sedangkan reaksi negatif ditandai dengan warna kuning pada media. Uji $\mathrm{H}_{2} \mathrm{~S}$ menggunakan media Triple Sugar Iron (TSI). Bila terbentuk warna hitam pada media berarti bakteri tidak mampu membentuk $\mathrm{H}_{2} \mathrm{~S}$ tapi bila terbentuk warna kuning berarti bakteri mampu membentuk $\mathrm{H}_{2} \mathrm{~S}$ dan uji bersifat negatif. Uji sitrat menggunakan media Simmons's Citrate Agar dan diberi label sesuai dengan kode biakan bakteri, dimana tabung berada pada posisi miring. Uji bersifat positif bila terjadi perubahan warna media dari hijau menjadi biru dan uji bersifat negatif apabila tidak tejadi perubahan warna pada media.

\section{HASIL PENELITIAN}

Hasil yang didapatkan dengan pewarnaan Gram ialah pada isolat SF 1(20), SF 1(40), SF 2(20), dan SF 2(40) Coccus Gram negatif sedangkan pada SF 
3(20) dan SF 3(40) didapatkan Bacilli Gram positif.

Tabel 1. Hasil uji morfologi

\begin{tabular}{ccc}
\hline Kode isolat & Bentuk & Bakteri Gram \\
\hline SF 1(20) & Coccus & Negatif \\
SF 1(40) & Coccus & Negatif \\
SF 2(20) & Coccus & Negatif \\
SF 2(40) & Coccus & Negatif \\
SF 3(20) & Bacilli & Positif \\
SF 3(40) & Bacilli & Positif \\
\hline
\end{tabular}

Hasil pengujian pada isolat didapatkan enam isolat menunjukkan hasil positif yaitu pertumbuhan bakteri yang menyebar baik disekitar tempat penusukan sampai di permukaan media. Koloni yang terbentuk pada media agar datar berwarna putih keruh dan menyebar sampai ke permukaan media.

Hasil yang didapatkan pada uji indol menunjukkan bahwa hanya dua isolat yang menunjukkan hasil positif, yaitu terbentuknya cincin berwarna merah di permukaan media setelah diberikan 5 tetes reagen Kovac's. Hal ini menunjukkan bahwa bakteri mengandung enzim triptofanase yang merupakan katalisis pengurai gugus indol yang terkandung di dalam asam amino triptofan.

Pada uji $\mathrm{H}_{2} \mathrm{~S}$ dengan menggunakan TSIA (triple sugar iron agar) didapatkan hasil yang negatif pada keenam isolat karena tidak terbentuk endapan berwarna hitam pada dasar dari media yang berarti bakteri tidak dapat membentuk $\mathrm{H}_{2} \mathrm{~S}$.

Isolat SF 1(20), SF 1(40), SF 2(20) dan SF 2(40) memberikan perubahan warna pada dasar (butt) menjadi warna kuning sedangkan pada bagian miring (slant) tetap berwarna merah. Terjadi pembentukan gas pada dasar media sehingga dapat disimpulkan bahwa bakteri pada isolat tersebut dapat memfermentasikan glukosa, sedangkan untuk laktosa dan sukrosa tidak dapat difermentasikan. Isolat SF 3(20) dan SF 3(40) memberikan perubahan warna pada dasar (butt) menjadi warna kuning sedangkan pada bagian miring tetap berwarna merah. Tidak terjadi pemben- tukan gas pada dasar media, sehingga dapat disimpulkan bahwa bakteri pada isolat ini tidak dapat memfermentasikan glukosa, sedangkan untuk laktosa dan sukrosa dapat difermentasikan.

Hasil uji katalase yang dilakukan pada semua isolat yang ditumbuhkan pada media Nutrient Broth menunjukkan hasil positif pada keenam isolat dimana terdapat pembentukan gelembung gas. Hal ini menunjukkan bahwa bakteri memiliki enzim katalase yang berfungsi menguraikan $\mathrm{H}_{2} \mathrm{O}_{2}$ yang ditambahkan ke koloni bakteri menjadi $\mathrm{H}_{2} \mathrm{O}$ dan $\mathrm{O}_{2}$.

Uji sitrat digunakan untuk melihat kemampuan mikroorganisme menggunakan sitrat sebagai satu-satunya sumber karbon dan energi. Bila mikroba mampu menggunakan sitrat, maka asam akan dihilangkan dari medium biakan, sehingga menyebabkan peningkatan $\mathrm{pH}$ dan mengubah warna medium dari hijau menjadi biru. Hasil pengujian pada enam isolat menunjukkan hasil yang positif dimana terjadi perubahan warna media dari hijau menjadi warna biru. Hasil uji lisin dekarbosilase menunjukkan hasil positif pada keenam isolat dimana media berwarna lembayung (ungu) pada semua bagian baik di dasar media maupun di bagian media yang miring.

Setelah hasil dari identifikasi bakteri yang meliputi uji morfologi, fisiologi, dan biokimia diperoleh, kesemuanya digabungkan dan digunakan untuk menentukan bakteri yang terkandung pada masingmasing isolat. Untuk identifikasi bakteri digunakan panduan Bergey's Manual Derteminative of Bacteriology. ${ }^{6}$

Isolasi SF 1(20), SF 1(40), SF 2(20) dan SF 2(40), merupakan bakteri Gram negatif dengan bentuk kokus, dan uji motil positif. Pada uji biokimia didapatkan katalase, sitrat, dan lisin positif sedangkan indol dan $\mathrm{H}_{2} \mathrm{~S}$ negatif. Dari beberapa uji ini disampaikan kedua isolat ini digolongkan bakteri E. coli. Isolasi SF 3(20) dan SF 3(40) dengan pewarnaan Gram negatif dan berbentuk basil. Berdasarkan bentuknya maka isolat ini dikelompokkan kedalam bakteri Bacillus sp yaitu bakteri Gram 
Positif dengan uji motil, uji katalase, uji sitrat dan uji lisin diperoleh hasil positif dan negatif pada uji $\mathrm{H}_{2} \mathrm{~S}$ dan uji indol positif. Koloni bakteri yang terbentuk berwarna putih keruh dan diinokulasikan ke media agar miring masing-masing 1 isolat untuk tiap cawan Petri. Isolat yang terbentuk semuannya berwarna putih keruh dan digunakan untuk dilakukan identifikasi bakteri.

\section{BAHASAN}

Pada penelitian ini dilakukan isolasi bakteri resisten merkuri dengan cara mengambil larutan sampel feses. Pada kosentrasi $10 \mathrm{ppm}, 20 \mathrm{ppm}$, maupun 40 ppm didapatkan ada pertumbuhan bakteri pada tiap isolat.

Bakteri adalah suatu organisme yang jumlahnya paling banyak tersebar luas dibandingkan organisme lainnya di bumi. Bakteri memiliki jumlah spesies mencapai ratusan ribu bahkan lebih dan merupakan prokariot unisel yang hanya diamati dengan menggunakan mikroskop. Bakteri dapat hidup secara sendiri-sendiri (soliter) atau berkelompok (koloni). ${ }^{7}$

Berdasarkan hasil penelitian yang dilakukan dengan mengambil sampel feses pada 3 orang pasien tumpatan amalgam di Puskesmas Bahu, ditemukan bakteri dengan ciri dan karakter berbeda. Hasil uji resistensi merkuri $\left(\mathrm{HgCI}_{2}\right)$ dengan konsentrasi 10 ppm, 20 ppm dan 40 ppm menunjukkan bakteri semua isolat tumbuh dengan baik. Konsentari merkuri yang diteliti ialah 20 ppm dan 40 ppm dengan pertimbangan semakin tinggi konsentrasi merkuri semakin toksik dan diinkubasi selama 24 jam.

Kemampuan resistensi setiap bakteri yang diperoleh terhadap merkuri berbeda. Perbedaan resistensi ini berhubungan dengan mekanisme respon populasi bakteri terhadap merkuri dengan metabolisme sel melalui sistem operon resisten dalam plasmid. Selain itu suhu dan $\mathrm{pH}$ merupakan faktor lingkungan yang sangat penting untuk kehidupan bakteri. Suhu rendah dapat menyebabkan aktifitas enzim menurun sedangkan suhu terlalu tinggi dapat mendenaturasi protein enzim. Pada suhu optimum pertumbuhan bakteri berlangsung dengan cepat. Di luar kisaran suhu optimum pertumbuhan bakteri menjadi lambat atau tidak ada pertumbuhan. 8

Hasil dari identifikasi bakteri yang meliputi uji morfologi, fisiologi digabungkan untuk menentukan bakteri yang terkandung pada setiap isolat. Penentuan bakteri dilakukan dengan menggunakan panduan Bergey's Manual Determinative of bacteriology. ${ }^{6}$ Dari hasil pemeriksaan Gram, didapatkan keenam isolat bakteri menunjukkan basil Gram negatif. Hasil identifikasi menunjukkan dua jenis bakteri yang resisten merkuri, yaitu, E.coli dan Bacillus sp. Hasil penelitian ini serupa dengan hasil penelitian Masloman ${ }^{10}$ yang mendapatkan dua jenis bakteri yang resisten terhadap merkuri yaitu E.coli dan Bacillus sp. Hasil penelitian ini juga tidak jauh berbeda dengan hasil penelitian Yorgen $^{11}$ dan Sarapi ${ }^{12}$ yang mendapatkan empat genus bakteri yang resisten terhadap merkuri yaitu E.coli, Bacillus sp, Streptococcus sp dan Staphylococcus sp.

Berdasarkan hasil penelitian isolat SF 1(20), SF 1(40), SF 2(20) dan SF 2(40), merupakan bakteri Gram negatif dengan bentuk kokus dan motil. Pada uji biokimia didapatkan katalase, sitrat, dan lysin positif sedangkan indol dan $\mathrm{H}_{2} \mathrm{~S}$ negatif. Dari beberapa uji ini disimpulkan bahwa keempat isolat ini digolongkan bakteri $E$. coli yang merupakan flora normal yang banyak ditemukan dalam saluran cerna manusia dan dikeluarkan melalui feses. E. coli merupakan bakteri batang Gram negatif yang resistens terhadap panas, dimana media tumbuh optimumnya sekitar 30-37 ${ }^{\circ} \mathrm{C}$. E. Coli hanya dapat tumbuh pada konsentrasi $\mathrm{HgCl} 20 \mathrm{mg} / 2100 \mathrm{ml}^{13}$

Isolasi SF 3(20) dan 3(40) pada pewarnaan Gram, bakteri merupakan Gram negative dengan bentuk basil. Berdasarkan bentuknya maka isolate ini dikelompokkan kedalam bakteri Bacillus sp. yang merupakan bakteri Gram negatif dengan uji motil, uji katalase, uji sitrat dan uji lysin diperoleh hasil positif tetapi negatif pada 
uji $\mathrm{H}_{2} \mathrm{~S}$ dan uji indol positif. Hasil penelitian ini serupa dengan penelitian Sarapi $^{12}$ yang mendapatkan bakteri Gram negatif yang motil, indol positif, katalase positif, memfermentasikan laktosa, sukrosa dan gas, uji sitrat dan lisin positif serta $\mathrm{H}_{2} \mathrm{~S}$ negatif dalam feses.

Hasil pengujian bakteri ini mirip dengan Bacillus sp. Di dalam tubuh manusia terdapat berbagai macam bakteri, di antaranya terdapat bakteri yang resisten terhadap merkuri dan eritromisin seperti bakteri Bacillus sp yang dapat mendetoksifikasi merkuri dengan mengubah bentuk $\mathrm{Hg}^{2+}$ yang memiliki sifat toksik menjadi bentuk $\mathrm{Hg}^{0}$ yang bersifat volatile dan tidak toksik di bandingkan dengan bentuk $\mathrm{Hg}^{2+}$. Bakteri ini memiliki seperangkat gen mer operon, sehingga mampu mengubah bentuk merkuri yang bersifat toksik menjadi tidak toksik. Bakteri Bacillus sp juga membentuk esterase yang menghidrolisis makrolid yang menyebab-kan terjadinya resisten bakteri ini terhadap antibiotik eritromisin. ${ }^{14}$

\section{SIMPULAN}

Dari hasil penelitian terhadap feses pasien tumpatan amalgam Puskesmas Bahu dapat disimpulkan bahwa terdapat 2 genus bakteri resisten merkuri yaitu E.coli dan Bacillus sp.

\section{UCAPAN TERIMA KASIH}

Ucapan terima kasih disampaikan kepada Widhi Bodhi, S.Si, M.Kes. Apt, Dr. dr. Billy Kepel, M.Med.Sc, Prof. Dr. Hj. Fatimawali, M.Si, Apt, Dr. dr. Aaltje E. Manampiring, M.Kes, dan semua pihak yang baik secara langsung maupun tidak langsung telah menumbuhkan ide dan gagasan pada penulis.

\section{DAFTAR PUSTAKA}

1. Combe EC. Notes on dental materials (6th ed). London: Churchill Livingstone, 1992.

2. Craig RG, Powers JM. Restorative Dental Materials (11th ed). St. Louis: Mosby, 2002.

3. Marek M. The release of mercury from dental amalgam the mechanism and in vitro testing. $\mathrm{J}$ Dent Rest. 1990;69:5.

4. Harper HA, Rodwell VW, Mayes PA. Review of Physiological Chemistry (17th ed). New YorkLange Medical Publication. 1990.

5. Suheryanto, Soetarto ES, Sugiharto E, Djohan TS. Bakteri resisten metilmerkuri dari sedimen sungai Sangon Kulonprogo DIY. Berkala Ilmiah Biologi. 2008;7(2):43-51.

6. Breed SE, Murray EGD, Hitchens AP. Bergey's Manual Determinative Bacteriology. Baltimore: The William and Wilkins Company, 1948.

7. Brooks FG, Butel SF, Morse AS. Mikrobiologi Kedokteran Jawetz (23rd ed). Jakarta: EGC, 2007.

8. Fatimawali, Watmawati B, Irawan $Y$. Isolasi dan identifikasi bakteri resisten merkuri dari muara sungai Sario yang dapat digunakan untuk detoksifikasi limbah merkuri. Jurnal Ilmiah Sains. 2011;11(2).

9. Immamudin $\mathbf{H}$. Pola pertumbuhan dan toksisitas bakteri resisten $\mathrm{HgCl}_{2}$. Jurnal Ekosains. 2010;2(1).

10. Masloman DK. Identifikasi bakteri resisten merkuri di muara sungai Talawaan di Teluk Manado [Skripsi]. Manado: Fakultas Kedokteran Universitas Sam Ratulangi; 2010.

11. Yorgen M. Identifikasi bakteri resisten merkuri pada karang gigi, urin, dan feses pada individu Kelurahan Pakadoodan Kota Bitung [Skripsi]. Manado: Fakultas Kedokteran Universitas Sam Ratulangi; 2014.

12. Sarapi D. Identifikasi bakteri resisten merkuri dalam urine, feses, dan karang gigi pada individu di daerah pesisir pantai Desa Pulisan Kecamatan Likupang Timur Kabupaten Minahasa Utara. e-BM. 2014;2(2).

13. Manampiring A, Kepel B. Studi populasi bakteri resisten merkuri di daerah aliran Sungai Tondano. [cited 2014 Oct 10]. Available from: http://www.sulutiptek.com/document s/merkuriketangbaru.pdf

14. Selin NE. Global biogeochemical cycling of mercury: a review. Annual Review of Environment and Resources. 2009. 34:43-63. 